<総 説 $>$

\title{
人体に安全な量子ドットの開発とその応用 Development and the Application of Non-toxic Quantum Dots for Human Body
}

\author{
山本 健二*・紙野 圭** \\ Kenji YAMAMOTO and Kei KAMINO
}

\section{1.はじめに}

量子ドットは, 日本の理論物理学者である久保亮伍によっ て一桁ナノメートルほよ゙の大きさを有する金属原子の結晶 （クラスター）は，大きなバンドギャップを生じる事を 1960 年代に理論的に初めて示された。その後マサチュー セッッ工科大学の科学科の Bawendi のグループは, 高温 の TOPO 溶媒としカドミウム源とセレン源を同時に注 入し分散させ，粒子サイズの揃った CdSe ナノ粒子を製 造することに成功した。この半導体ナノ粒子は，その粒子 サイズにより異なる蛍光色を持ち，より小さな粒子サイズ の持つナノ粒子は，大きなバンドギャップを持つ事が確認 された。さらにこのナノ粒子の表面を $\mathrm{ZnS}$ で被覆する ことにより更に高い量子效率を有することが判明し，更に 安定で大きな蛍光強度を有する蛍光ナノ粒子を得るに至っ た。

初めて製造された半導体ナノ粒子は, CdSe や CdS など II 族 VI 族の半導体でイオン化すれば，毒性の強い元素を 用いて行なわれていた。一方, 金属カドミウムは, イオン 化したカドミウムに比べ毒性が低い事から，力ドミウムと セレンの半導体ナノ粒子は, 毒性が低いとも考えられてい た。また ZnS で被覆することにより安定化し，さらに毒 性が低く，また蛍光輝度屯高くなる事が判明した。

* 国立国際医癔センター, 臨床研究センター・センター長 東京都新宿区戸山 1-21-1 ₹ 162-8655

International Medical Center of Japan, International Clinical Research Center, Director General

1-21-1, Toyama, Shinjuku, Tokyo, 162-8655 Japan

**（独）製品評価技術基盤機櫣 バイオテクノロジー本部

千葉県木更津市かずさ鎌足 2-5-8 テ 292-0818

Department of Biotechnology, National Institute of

Technology and Evaluation

2-5-8 Kazusakamatari, Kisarazu-shi, Chiba 292-0818 Japan

\section{2. 製造法}

量子ドットの製造方法は，各々のクラスターの成分によっ て異なるがホットソープ法，レーザエッチング法，化学エッ チング法, 超臨界水熱反応法などが開発されている。ホッ トソープ法はトリオクチルフォスフィンオキサイドなどの 有機溶媒に逆ミセルを作り，その超微小空間内に，クラス ターを自己組織化させ，さらに表面加工することにより安 定化させる製造方法である。2 族 6 属のカドミウムとセレ ン等の半導体ナノ粒子を製造する時に利用され，現在は一 度に $1 \mathrm{~g}$ 程度製造できている。レーザエッチングは硫化亜 鉛 $(\mathrm{ZnS})$ 半導体ナノ粒子を製造するときに利用されてい る方法であり，用いるレーザーの波長によりナ粒子のサイ

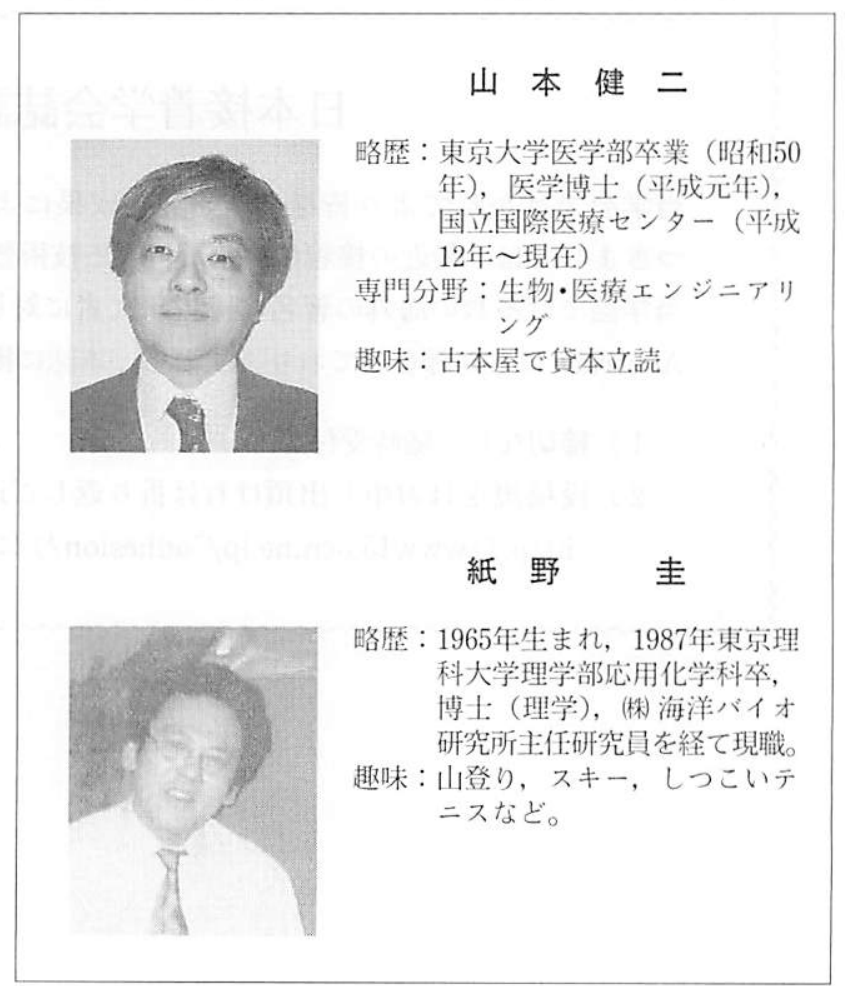


ズを正確にコントロールできる。化学エッチング法は，例 えばフッ酸を用い水溶液中で 4 族元素であるシリコンナノ 粒子を製造するときに利用されている。超臨界水熱反応は, 水あるいはイソプロパノール等の溶媒を用い高温高圧下に ナノ粒子を製造する方法である。このように製造された半 導体や金属酸化物クラスターは, 疎水的であり, 有機溶媒 にのみ分散可能である。目的に依っては，水溶性を得る為 に，各々の製造法による極めて特徴的な方法により表面加 工が行なわれ，蛍光ナノプローブなよ゙生物・医療応用に用 いられている。表面加工の例として分子としては, 有機酸, アミン，スルフォン酸，アミノ酸やペプチド，糖，テレペ ンなど小分子からタンパク質など生体ポリマーやポリエチ レングリコール等の化学合成ポリマーなどの高分子に至る まで多くの試みが行なわれている。

\section{3. 半導体ナノ粒子の生物合成}

一方, 半導体ナノ粒子は, 人工的に作られるのみならず, 生物で屯作っている事が知られている。例えばパンを作る 時に用いられる酵母の仲間では, 栄養源が十分有るときは, 細胞分裂が起こり指数関数的に増殖している。このような 対数増殖機に於いては，培養液中にカドミウムイオンやや セレンイオンが存在しても特に変化はなく增殖し続ける。 培荃液の栄意が枯渇してくると通常, 細胞增殖は遅くなり 最後には細胞分裂が停止する。このような状態に至った醉 母:，その細胞内に CdSe 半導体ナノ粒子を製造する事が 知られている。セレンイオン濃度が十分無い場合でも, ア ミノ酸のシスティンの $\mathrm{S}$ 元素を用いて $\mathrm{CdS}$ 半導体ナノ粒 子を製造することができる。この製造過程に於いてその粒 子径が時間ととあに大きくなってくることから，蛍光顕微 鏡で観察するとその蛍光色は緑から黄色, 橙色, 赤色と変 化してくることが報告されている。このような半導体製造 するための代謝経路をなぜ酵母が持っているかは現在不明 である。この他にも例えば磁性粒子を作る細菌が存在する (磁性細菌)。醅母は真核生物であり, 磁性細菌は原核生物 である。両者ともに単細胞生物であるが，ヒトとサボテン の隔たりより遥かに遠い存在である。またヒトであある種 の疾患を持っておられる方の肝臓に銅や鉄粒子が凝集する ことが知られている。これらの現象には, 金属, 半導体粒 子を製造することの意義についての多くの理由が存在する であろうが, 説明可能でかつ簡単な一つの理由として, 金 属イオンの毒性を中和する為に存在するのでは無いかと言 う考えが挙げられる。

実際に酵母存用いてこのような半導体ナノ粒子合成法が 産業に利用されるとも思われるが, 前述の Bawendi らが 行なった合成法を用いたものに比べ，粒子径分布は広く， そのため現在のところ産業用としては用いられていない。 しかし, 上壤污染を中和する為の方法としての展開が今後
期待される時が来るだろうと筆者は, 考えている。さらに また，半導体ナノ粒子を製造する時には，トルエンなどの 有機溶媒に, TOPO や TOAB 等と言った界面活性剤に使 用する有機物に毒性が強いため, 製造後これらの除去法を 十分に考えておかないといけないことが, 生物を利用して 合成する方法のもう一つの有利な点であある。

\section{4. 安全性}

ある材料を産業に利用する場合, 現在では必ず安全性に ついて調べておく必要がある。人体への直接の安全性と, 工業廃液など環境への安全性が必要と成っている。ある一 定の值を設定し，その基準值より上回る值を示すことは, 許されていない。この值が国ごとに異なった基準を設けた 場合, 日本から材料を輸出することを考えてみると, 生産 国である日本の基準を，まず満たしておいた上で，更に相 手国の基準を満たさなければ成らない。また日本から輸出 され，相手国で材料として利用された製品を，更に第三国 に翰出された場合その国の基準を満たしていなければ成ら なくなる。このため, 現在の世界情勢を考えた場合, 最む 廠しい基準值に依存されることが少なく無い。

量子ドットは, 産業化への様々な研究開発が行なわれて いる。細胞毒性試験において, 毒性を現す限界濃度（閾值） が，既に報告されている。細胞毒性だけが報告されていて 閾值が求められていない場合, その存在が危険であること になり，そのため内分泌かく乱物質のようなむのとして認 識されることとなりかねない。

量子ドットの毒性において閾值は, 製造過程や, 表面加 工法によって異なる事が報告され ${ }^{1}$ ，より安全な製造方法 と, 表面加工の方法についての開発研究が積極的に展開さ れている。

また必ずしも安全性だけが原因でとは言えないが，量子 ドットを構成する元素に対しても検討されている。量子ドッ トとして開発されて来た順序は, 初め CdSe や CdS など II 族 VI 族の半導体, その後インジウム・燐など III 族 V 族の量子ドット，更にその後シリコン ${ }^{2)}$ や，ゲルマニウ 么等 IV 族元素を用いたすのが開発されて来た。毒性につ いて。より安全性の高い量子ドットの開発に配虑を来たと も考えられる。いずれにせよ, 安全性は最重要課題である が，現在のところ健康被害の報告はされていない。

\section{5. 表面加工法の開発}

量子ドットの表面加工法は，積極的に検討されている。 量子ドットが強い蛍光を発する事から，分子や細胞を染 色しその動態を観察するのに優れ，生物・医療応用された め, 水溶性之安全性が必要であった為である。生物・医療 応用されるあう一つの理由は, 生産量がまだ十分上がっ ていないため, 産業応用するには至っていないためでもあ 
る。

量子ドットは, Bawendi らが当初行なったホットッー プ法によって作られた場合, トルエンなどの有機溶媒には 可溶であるが, 水溶液にはほとんど溶解しないため生物・ 医療応用するには, 適さない。そのためには水溶性の量子 ドットが必要と成るため表面加工を行って水溶液中でも溶 解させることができる様にするか, あるいは籠状の水溶性 ポリマーに封埋するかの方法で行なわれている。表面加工 としては, 有機酸, アクリル酸, シロキ酸, アミンなどの 他, 糖やアミノ酸ポリマー, ポリエチレングリコール等で 行なわれている。これらの分子を用い表面加工を行い, 水 溶性量子ドットを製造し, 表面加工を行った分子の官能基 を用いて生体分子，例えば蛋白，オリゴペプチド，核酸な どに結合させることが可能である。さらに生物や医療応用 目的で使用する際に, 例えば実際培養中の細胞に導入する ことむあり，また経口から或は，注射にて生体内に投与す ること屯ある。その場合細胞内器官, 或は生体内臟器に於 いて $\mathrm{pH}$ が強酸から強塩基まで変化し, また更に塩濃度が 非常に高くなる状態にあ耐えなければならない。このよう な環境では, 水溶性表面加工を施していた量子ドットが, 異なる $\mathrm{pH}$ 環境や塩濃度環境により凝集することあある。 細胞や生体に導入する以前の問題として, 細胞培養液は塩 濃度も高く, 炭酸ガス培養器の中で $\mathrm{pH}$ が低くなり, さら に細胞が代謝した後で有機酸が生じることからも ph が低 くなる。このようなことから, 合成された量子ドットをそ のまま生物や医療に利用する事は, できない。それに対し, これまでの多くの努力により, 生物・医療応用に耐えうる 特性を持つ表面加工法が開発され，利用する事ができるよ うになっている。

\section{6. ナノメデシン}

厚生労働省では, 2002 年度科学研究予算としてナノメ デシン研究予算を編成した。循環器病センター, がんセン ター, 国際医療センターなどのナショナルセンターを中心 にバイオイメージングによる疾病解明, 医療用超微小デバ イスの開発, 量子ドットによる薬剤伝達システムの開発が 行なわれた。我々の研究グループは, 量子ドットの人体一 の安全性を検討しながら, 人体に用いられる安全なナノ粒 子の開発を行ない, 特に薬剤伝達キャリアーとして用いる 事老目的に行なった。ここで言う, 薬剤伝達キャリアーと は, 薬物を何らかのデバイスを用いてターゲットと成る臟 器, 細胞, 細胞内小器官に送達させるそのデバイスの事を 言う。量子ドットによる薬剤伝達システムの開発研究班に は, 国際医療センター, がんセンター, 循環器病センター が参加し, 国際医療センターにおいては, 半数以上の研究 部が参加し, 更に国立感染症研究所, 東京大学, 神戸大学, 東京薬科大学, 横浜栄共済組合病院が研究に参加した。医
学と工学の連携, 臨床と基礎の連携が行なわれた。量子ドッ トによる薬剤伝達システムの開発研究班は, 人体に使用す る事が可能な, 安全で安心な量子ドットを開発し, それを 医療デバイスとして人体の局所を夕ーゲットに薬物や遺伝 子などを送達するシステムの開発することが目標である。 このような薬物伝達システムを用いると, 薬剤としては毒 性が強く全身すると副作用が出るようなものでも, 少量で 局所の病巣に集める事が可能で, そこで高濃度の薬物治療 が実現可能となる。例えば癌で手術するには遅くなってし また場合, 或は手術後再発し人体の他の場所に転移した場 合にもターゲットした薬剤伝達キャリアーによって薬物を 単独で全身投与するより少ない量で効果を上げる事が考え られる。現在すでにこの機能を持つナノキャリアー（粒子 径が $100 \mathrm{~nm}$ から $50 \mathrm{~nm}$ のスブミクロンサイズ)）が開発さ れている。例えば，親水性ポリマーに疎水的ポリマーを結 合させたブロックポリマーは, 水溶液中では, ミセルを構 成する。このミセル内に薬物を包埋し, 生体に注入して疾 患部に到達させる事が, 可能である。この方法でのガン治 療の治験は, すでに開始されている。それ以外でむコラー ゲン分子のアレルゲンなどの原因となる, 断端部を切断し たアテロコラーゲンをキャリアーとする方法す iRNA を 治療に試みられている。特に米合衆国では, ガン治療以外 にも様々な分野に於ける疾病治療への治験プログラムが進 行している。

量子ドットに依る薬羭伝達システム3) の特徵は，1）薬 物伝達キャリアーの大きさが一桁 $\mathrm{nm}$ サイズであると言う 点, 2) 薬物は, 内包されるのではなく外郭に結合されて いる点，3）薬物伝達キャリアーは，それが発する蛍光に より細胞内, 臟器内, 生体内で追跡可能である点などが挙 ザられる。

その他の薬物伝達キャリアーとして, カーボンナノチュー ブやフラーレン, 磁性ナノ粒子などの開発研究が現在, 世 界中で淩ぎを削って行われている。

\section{7. 生物医療応用}

生物・医療応用として挙げられる量子ドットの特性とし ての一つは, 有機蛍光色素に比べて非常に強力であること, またその持続時間が非常に長いことである。通常の蛍光顕 微鏡観察に於いては, 有機蛍光物質によるとわずか 5 分足 らずで消光するのに対し量子ドットは，1時間以上む十分 な蛍光強度を保つことが可能である。また有機蛍光色素の 励起光は, 蛍光波長より短波長側に於ける特定の波長のみ 有効であると言うような制限がある。量子ドットの場合, 蛍光波長より短ければ励起可能である点有利である。サイ ズの異なる量子ドット粒子は, 紫外線などを用い一種類の 励起光で量子サイズ効果によりそのサイズに依存した蛍光 を同時に観察する事が可能となる。例えば異なる抗体に蛍 
光色の異なる量子ドットを結合させサンプルを染色するこ とが同時に行うことが可能となる ${ }^{4)}$ 。一方従来の方法では, 異なる本数の励起光を照射し, それから得られるイメージ データを合成する演算デバイスが必要と成る。光学顕微鏡 観察より更に微小なレベルとして一分子イメージングがあ る。これは一つの分子に蛍光色素を結合させ, その分子蛍 光色素複合体から発せられる強力な蛍光を通常の光学顕微 鏡でその動態, 局在を観察する方法である。これを実現す るには, 強力な蛍光を発する蛍光色素と微小な光を感知す る計測機器が必要である。このため一分子の計測における 空間解像度と時間解像度を上げることが, 連続的にその複 合体を追跡するには必須である。当初の CdSe による量子 ドットは, 粒子直径が $5 \mathrm{~nm}$ 程あり, 対象とされる一分子 に対して大きいと言う欠点があったが最近の量子ドットは, 更に小さいサイズの物む開発されているので今後の発展が 期待できそうである。

\section{8. 量子ドットと有機化合物との結合}

量子ドットの形状は, 小さい場合は, ポリゴン, 大きい 場合は,ほぼ球状に成っている。量子ドットは, 薬物など 低分子からペプチド，核酸から遺伝子や抗体などの高分子 にも結合する事が可能である。その表面之直接, 或は適当 なアダプター分子を介してこのような低分子や高分子に結 合することが可能である。我々は, 量子ドットと抗体との 結合には, アダプター分子を介して結合させている5)。量 子ドットが球状である事からその球表面に対して対象に成っ ている。そのため, 量子ドットの結合する抗体も複数個結 合する。

炭素と結晶を直接結合させる場合, すなわち例えば 4 族 元素のシリコンを用いた，シリコンドットを用いて結晶表 面のシリコンと表面加工の炭素系有機物との結合をさせる。 その場合, 表面の $\mathrm{Si}$ 分子と分子端に $\mathrm{C}=\mathrm{C}$ 二重結合を有 する化合物とを適当な触媒で $\mathrm{Si}-\mathrm{C}$ 共有結合させることが 可能である。現在我々は,このように薬物を付けた量子ドッ トを動物体内に導入し，その生体内動態を観測している。 このように薬物を結合した量子ドットを, 疾病モデル動物 に導入し，蛍光強度を計測することにより，経時的に血中 内濃度を測定することが可能である。現在, 米合衆国では, すべての新規薬物は，それを人体に投与する前に，ひとつ は CYP450などの薬物代謝に関わる多くの遺伝子のなか で，その対象之成る薬物に実際どの遺伝子が関与している かを調べて提出すことを義務付けている。すう一つの提出 義務として人体の薬物動態データがそれである。

ところがラジオアイソトープは，リアルタイムに生体内 の薬物動態を钼察するのに適していない。その点について 量子ドットのタグをつけた薬物は，有利である。その点に 付いてトレーシング機能を備えた, 薬䬉キャリアーとして
の量子ドットの役割も将来的には実用化されると考えてい る。

またこのデータから半減期を計算する事も可能であり, カプトプリルなど幾つかの薬物について, 従来法で計測し た半減期とほぼ同じ值を示した ${ }^{3)}$ 。

以上の様に量子ドットは，その特性を利用して薬物等の 低分子から抗体などの巨大タンパク質に至るまで分子プロー ブとして利用する事が可能である。強力な蛍光強度を有す るその複合体は, 細胞, 生体内レベルでの経時てき動態解 析を行なうのに大変適している5)。さらにまた細胞染色に よって，興味ある細胞の生体内動態を経時的に観測するこ とが可能である ${ }^{6)}$ 。今後の細胞生物学に大きな寄与をむた らすと信じている。

\section{9. 分子局在変化による診断治療}

一つの例として, 急性進行性系球体腎炎についての応用 を以下に示す7)。急性進行性系球体腎炎は, 老人に多い疾 患で高熱, 乏尿, 血尿, 蛋白尿, 高血圧, 全身倦怠などが 急性に起こり急性腎不全となり，放置すればしにいたる。 この症状を起こした 55\%の患者は, pauci-immune型と よばれ，抗好中球細胞質抗体 (ANCA)によってミエロぺ ルオキシダーゼ (MPO) が分泌されることによりこれら様々 な症状が起こる疾患である。好中球の MPO は, 好中球細 胞質内に通常局在しているものであるが, TNF $\alpha$ や細菌菌 体抗原 FMLP で刺激すると好中球細胞質内から細胞膜に 移動する。抗 MPO 抗体に量子ドットを結合させそれを用 いてMPO を染色ことが可能である。通常の有機色素では, 蛍光強度が十分ではなく, 観測できない程少量の MPOに 結合した抗 MPO 抗体一量子ドット複合体を十分観測する 事が可能である。MPO は, 細胞質内に存在するため, 細 胞の外側から標識化抗体は，MPO に結合することができ ない。例えば界面活性剂で細胞膜を壊すと細胞内に存在す るMPO を標識化抗体で染色することが可能である。 TNF $\alpha$ や FMLP で刺激すると細胞膜上に移動した MPO を観測することが可能である。一方活性化した好中球は, TNF $\alpha$ やFMLP で刺激しなくても, MPO は, 細胞膜上 に存在する為この方法により染色する事により蛍光顕微鏡 観察が可能である。このような方法で好中球の活性化を検 査することが可能である。実際 RPGN の疾患により入院 された患者では, 健常者に比べ有為に好中球細胞膜上に存 在する MPO を観測する事が出来る。

治療法の一つの方法として $\gamma$ グロブリン療法がある。こ の治療により軽快した患者の MPOは, 好中球細胞膜上よ り消失することが量子ドットを用いた検査法で判明した。 これにより量子ドットによる疾病の診断が可能と成り, ま た治療効果が有効であるか否かの評価することも可能な新 規の有効な検査法が開発されるに至った。 


\section{0. 細胞染色による生体内細胞動態観察}

あう一つの量子ドットの持つ強い蛍光を利用した例を以 下に紹介する。そ扎は，生きたまま細胞を量子ドットで染 色しその生体内動態を追跡する技術と，その技術によって 疾病メカニズムを解析する方法である ${ }^{8)}$ 。その目的に十分 注意しなければ成らない事は, 安全性についてである。量 子ドットの細胞毒性は, 量子ドットの製造過程と表面加工 に大きく依存する事は, 前述の通りである。

製造過程に存在する毒性を示す不純物を十分除去するか, あるいはそのような製造過程を選ばない事が重要である。 また量子ドットの表面加工物質と生体分子, との表面相互 作用が，安全性に対して重要であることが示唆されている。

この条件を備えた量子ドットを用いて興味ある細胞を染 色し, 生体内に導入し導入し, 各㵴器でどこに局在してい るか，時間を追って解析する事が可能と成った。このよう な例として, 我々は, マクロファージを対象として研究を 進めている。実際にこれまで腹腔マクロファージや破骨細 胞を使った細胞動態解析実験が成されている。下部消化管 の炎症に関与する免疫細胞の一種である腹腔マクロファー ジを腹腔より取り出し，生きたまま量子ドットで染色し， それを動物生体内に戻して観察する。具体的には腸に潰瘁 を起こした疾患モデルマウスに静脈から投与したところ潰 瘍面の腹膜側に集積していた。一方，骨髄細胞から，マク ロファージを誘導し量子ドットで染色し上記疾患モデルマ ウスに経静脈にて同様に投与したところ潰瘍面の腸間腔側 に集積していた。骨喵で生まれたマクロファージと腹腔に いる腹腔マクロファージとでこのような動態変化は何で起 こるのだろうかと言う興味がわく。腹䐁マクロファージと 骨骾細胞から誘導したマクロファージでは, 何が異なるの だろうか。様々な角度から, その変化を調べたところ細胞 表面に発現しているケモカインレセプターが異なっている 事が判明した。実際調べてみる骨䯣から誘導したマクロ ファージは, 様々なケモカインレセプターが発現している のだが, 腹腔マクロファージは, ケモカインレセプターの CCR8のみの発現が強く起こっていることが判明した。ま たこのケモカインレセプターの CCR8 は, CCL1 と言う低 分子のリガンドのレセプターであることが知れている。そ こで骨檤細胞から誘導したマクロファージにCCL1 を与. えてみると腹膜内皮細胞之強い相互作用を示し, シャーレ 内での実験では, 腹膜内皮細胞とのマクロファージの団子 状の細胞の塊を形成することを確認した。さらにまた， CCL1 に対する中和抗体によってこう言った腹膜内皮細胞 之強い相互作用が無くなり塊を形成しないことが判明した。 その後この CCL1 を放出する細胞は, 腹腔マクロファー ジと腹膜内皮細胞であることが明らかと成った。即ち，骨 䯣細胞から生まれたマクロファージが, 腹膜内皮細胞の近
く来た時 CCL1 に反応することによりマクロファージに 成る過程が推察される。またこの現象が, 消化器疾患との 関係について手術後癒着と強く関係している事が判明した。 手術後瘑着のモデルマウスを利用し CCL1 抗体で腹腔マ クロファージの塊を作るような活性化をブロックしてみた ところ, 手術後の癒着を予防する事が判明した。これまで に既に, ヒトに於いても下部消化器疾患の手術後, ドレー ン廃液内に CCL1 が有為に高くなるという結果が得られ ている。この事から考え合わせると, 一般の手術後癒着に 対する予防法を開発が可能であると考えている。

\section{1. 接着性蛋白質やペプチド研究のツールとしての $\mathrm{QD}$ の利用}

近年，核酸や蛋白質/ペプチド等の生体分子を材料とし て利用するための研究が広がりをみせている。核酸の相補 的な認識力や, 蛋白質の特異的な認識力, あるいはナノ構 造の形成力等を利用しようというというわけである。生物 自信も蛋白質を材料として用いることが多い。例えば，シ ルクは人と昆虫それぞれにとって材料なのである。その他 にも, 生物自信が材料として用いている分子（生体分子材 料）は多々あるが, 生体分子として理解が進しでいるあの は未だ限られている。それら生体分子材料を丁寧に解読し， あらゆる角度からその知見を利用することによって, 再生 医療やナノテクノロジーの発展を支える新たな材料を実現 できるのではないだろうか。

生体分子材料系蛋白質の知見を利用するには，いくつか の方法がある。例えば， 1. 蛋白質として利用する（ここ では蛋白質材料之呼ぶ），2. その物性発現に重要な化学構 造単位だけを模做して利用する, 3 . その物性発現に重要 な分子の空間配置を化学合成材料で模做する，4. その物 性発現に関与する変換（酵素反応，化学反応）系を利用す る, 等の方法を挙げることができる。2.や3.はより安価 に大量に製造できる可能性があるが，時に行き過ぎて，生 体分子材料の持つ良さからかけ離れてしまう傾向がある。 4. は, 生体適合性材料研究等でみかけるが, 応用性の高 い重要な観点である。1.は，生体分子材料の良さを多く 残すことができるが，製造をバイオプロセスに頼ることと なり, 安価で大量な製造過程には未だ不安がある。但し, 微量にしか用いない, あるいは高価でも利用される分野で あれば可能性はある。また，実用化に際して蛋白質やペプ チドの物性を最適化していく必要があり, その物性スクリー ニング過程にも不安がある。実験室レベルで準備できるサ ンプル量はがんばってあ通常〜数百マイクログラムであり, できれば数マイクログラム程度で測定できることが望まし い。しかし，接着や自己集合等の物性を微量でスクリーニ ングできる手法は限られており, また high throughput 化に適さない煩雑さをむっていたりもする。生物が進化さ 


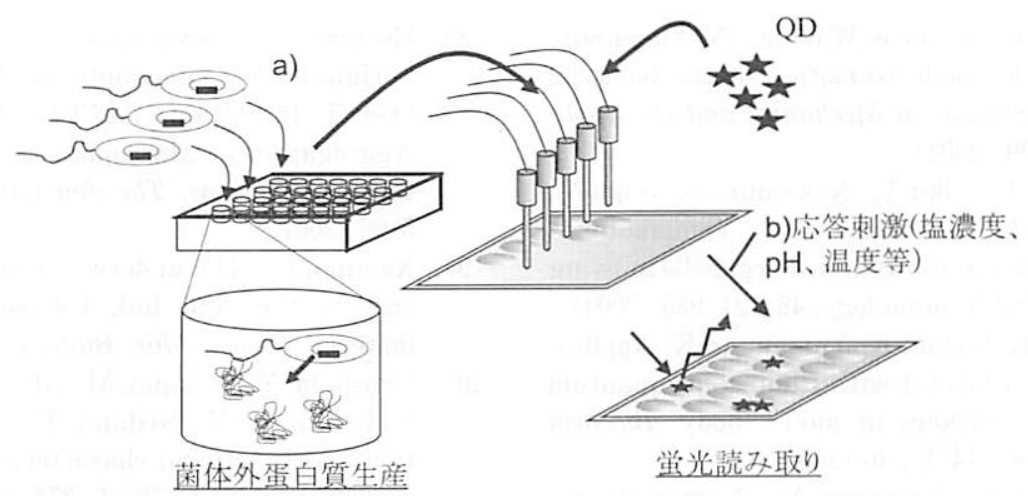

図 1 QD 老利用した蛋白質/ペプチド性材料の改変のためのスクリーニング系 a）水中接着性蛋白質/ペプチドのそれぞれの改变体を，菌体外に産生する組み換え微生物（あるいは無細胞発現系）。 b）利用に際して必要とされる応答刺激（塩濃度，特定金属， $\mathrm{pH}$, 温度等）

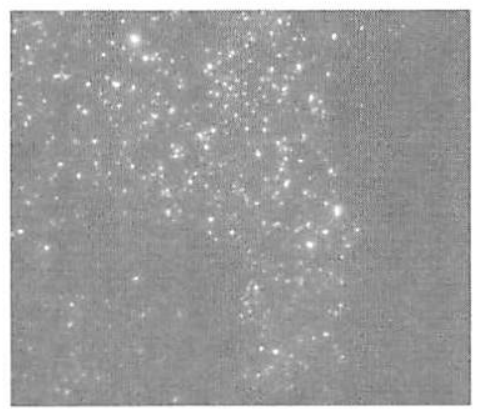

図 2 フジッボ水中接着蛋白質 $\left(19 \mathrm{kDa}\right.$-cement protein $\left.{ }^{10)}\right)$ による水中接着の検出蛋白質の接着能によってガラス 基盤上に接着した QD の全反射顕微鏡像

せた材料起改変して，その良さ在活かしつつ目的に応じた 条件で利用するには, 微量物性解析法の整備が求的られる のである。

ところで，未だ実現困難な技術のひとつに水中接着が挙 げられる。水圈付着動物の水中接着物質に学ぼうという姿 勢は古くからみられるが，その理解や利用は未だ入り口に ある。生物の進化させた生体分子材料群は, 私たちの予想 を超えた， ミクロからマクロに至る広い階層性にそれぞれ の分子機構を秘めており, 幅広い理解を通した利用研究が 求められるのである ${ }^{9}$ 。そこには多くの研究課題があるが, その実用化への道のりを考えると, 特にその物性の最適化 を行うための方法論が確立していない。そこで筆者らは, 微量で蛋白質/ペプチドの自己集合性や接着性をスクリー ニングする方法を検討している。そのひとつに, QD を利 用した簡便なスクリーニング法（図 1）がある。この方法 は，接着性を測定したい微量な蛋白質やペプチドを QD と混合し, 目的とする応答刺激で接着したサンプルを, 巻 き込まれて接着した QD（図 2）の蛍光測定で判別しょう というあのである。この方法では, サンプルのラベル化に よる構造／物性の变化や，未反応物の除去によるサンプル のロスはない。そのため，例えば菌体外に組み換え生産す ることができる系を用いれば，改変水中接着蛋白質やペプ チドのスクリーニングを high throughputに行うことが
でき，用途に応じた水中接着蛋白質/ペプチド性材料が開 発できる可能性がある。ここで QD を用いる利点は, そ のサイズが蛋白質分子と同等以下なことと，蛍光を発する という点である。非常に単純な原理だが，菌体外組み換え 生産技術や液体ハンドリング手法等がうまく組み合わさる ことで，予想以上に威力を発揮すると考えている。

\section{2. 終わりに}

これまでに紹介した生物・医療応用以外にも量子ドット は，将来様々な産業領域で利用されると考える。しかし一 方では，安全性について化学物質とナノ粒子が同じ様に扱 う事が可能か，否かについてさえあ十分に判ってはいない。 我々は, 少なくとも化学物質之同じ様に取り扱った場合に 毒性が検出されるなら，その毒性を少なくする対策がとれ ると考えている。しかしながら，この程度で良いのであろ うか? 感染して何十年も経ってから発病する疾病が, 力ー ルトン・ガイジュセックによって半世紀程前に報告されて いる。現在広く知られている疾病であるクロイッフェルト・ ヤコブ病がそれである。しかし，発表した当時でさえ，ク ロイツフェルトレヤコブがその論文の内容を全面否定した と言う経緯がある。現在のナノ粒子の安全性についても同 様なことが言えるのでは無いかと考えている。ナノ粒子を 扱う研究者, 製造者が常に安全性に眼を向け健康被害に注 意する事が重要であると我々は感じる。

\section{参 考 文 献}

1) Shiohara A, Hoshino A, Hanaki K, Suzuki K, Yamamoto K. On the cyto-toxicity caused by quantum dots. Microbiology and Immunology, 48(9), 669 (2004).

2) Warner JH, Hoshino A, Yamamoto K., Tilley RD. Water -Soluble Photoluminescent Silicon Quantum Dots. Angew Chem Int Ed., 44(29), 4550 (2005).

3) Manabe N, Hoshino A, Liang YQ, Goto T, Kato N, Yamamoto K. Quantum dot conjugated with medicine as the drug tracer in vitro and in vivo. IEEE Transactions on NanoBiosciences, 5(4), 263 (2006). 
4) Eiha N, Komoto A, Maenosono S, Wakano JY, Yamamoto $K$, Yamaguchi Y. The mode transition of the bacterial colony. Physica A: Statistical Mechanics and its Applications, 313(3-4), 609 (2002).

5) Hoshino A, Fujioka K, Oku T, Nakamura S, Suga M, Yamaguchi Y, Suzuki K, Yasuhara M, Yamamoto K. Quantum dots targeted to the assigned organelle in living cells. Microbiology and Immunology, 48(12), 985 (2004).

6) Hoshino A, Hanaki K, Suzuki K, Yamamoto K. Applications of T-lymphoma labeled with fluorescent quantum dots to cell tracing markers in mouse body. Biochem Biophys Res Commun, 314(1), 46 (2004).

7) Hoshino A, Ohnishi N, Yasuhara M, Yamamoto K, Kondo A. Separation of Murine Neutrophils and Macrophages by Thermoresponsive Magnetic Nanoparticles. Biotechnology Progress, 23(6), 1513 (2007).
8) Hoshino A, Kawamura YI, Yasuhara M, ToyamaSorimachi N, Yamamoto K, Matsukawa A, Lira SA, Dohi T. Inhibition of CCL1-CCR8 Interaction Prevents Aggregation of Macrophages and Development of Peritoneal Adhesions. The Journal of Immunology, 178(8), 5296 (2007)

9) Kamino, K., The underwater adhesive of marine organisms as the vital link between biological science and material science. Mar. Biotech., 10, 111 (2008).

10) Urushida, Y., Nakano, M., Matsuda, S., Inoue, N., Kanai, S., Kitamura, N., Nishino, T., and Kamino, K. Identification and functional characterization of a novel barnacle cement protein. FEBS J., 274, 4336 (2007). 